\title{
Testosterone modulates cardiac contraction and calcium homeostasis: cellular and molecular mechanisms
}

\author{
Omar Ayaz ${ }^{1}$ and Susan Ellen Howlett ${ }^{1,2^{*}}$
}

\begin{abstract}
The incidence of cardiovascular disease rises dramatically with age in both men and women. Because a woman's risk of cardiovascular disease rises markedly after the onset of menopause, there has been growing interest in the effect of estrogen on the heart and its role in the pathophysiology of these diseases. Much less attention has been paid to the impact of testosterone on the heart, even though the levels of testosterone also decline with age and low-testosterone levels are linked to the development of cardiovascular diseases. The knowledge that receptors for all major sex steroid hormones, including testosterone, are present on individual cardiomyocytes suggests that these hormones may influence the heart at the cellular level. Indeed, it is well established that there are male-female differences in intracellular $\mathrm{Ca}^{2+}$ release and contraction in isolated ventricular myocytes. Growing evidence suggests that these differences arise from effects of sex steroid hormones on processes involved in intracellular $\mathrm{Ca}^{2+}$ homeostasis. This review considers how myocardial contractile function is modified by testosterone, with a focus on the impact of testosterone on processes that regulate $\mathrm{Ca}^{2+}$ handling at the level of the ventricular myocyte. The idea that testosterone regulates $\mathrm{Ca}^{2+}$ handling in the heart is important, as $\mathrm{Ca}^{2+}$ dysregulation plays a key role in the pathogenesis of a variety of different cardiovascular diseases. A better understanding of sex hormone regulation of myocardial $\mathrm{Ca}^{2+}$ homeostasis may reveal new targets for the treatment of cardiovascular diseases in all older adults.
\end{abstract}

Keywords: Aging, Excitation-contraction coupling, Gonadectomy, Orchiectomy

\section{Review}

\section{Introduction}

Cardiovascular diseases are a leading cause of hospitalization and death for both men and women [1]. As advanced age is a major risk factor for the development of cardiovascular disease in both sexes, the incidence and prevalence of these diseases is expected to escalate as our population ages [2]. The knowledge that the incidence of cardiovascular disease in women rises as estrogen levels fall after menopause has fueled interest in its potential cardioprotective effects [3]. What is less well appreciated is that testosterone levels also decline with advancing age, not just in men but in women too [4-6]. This suggests that low-testosterone levels may contribute to the pathogenesis of cardiovascular

\footnotetext{
* Correspondence: Susan.Howlett@dal.ca

'Department of Pharmacology, Dalhousie University, 5850 College Street, Sir Charles Tupper Medical Building, PO Box 15000, Halifax, NS B3H 4R2, Canada

${ }^{2}$ Medicine (Geriatric Medicine), Dalhousie University, 5850 College Street, PO Box 15000, Halifax, NS B3H 4R2, Canada
}

(C) 2015 Ayaz and Howlett; licensee BioMed Central. This is an Open Access article distributed under the terms of the Creative Commons Attribution License (http://creativecommons.org/licenses/by/2.0), which permits unrestricted use, distribution, and reproduction in any medium, provided the original work is properly credited. The Creative Commons Public Domain Dedication waiver (http://creativecommons.org/publicdomain/zero/1.0/) applies to the data made available in this article unless otherwise stated.

disease. Indeed, a number of clinical studies have shown that low endogenous levels of testosterone are associated with cardiovascular disease [4]. Furthermore, testosteronereplacement therapy, which is used to treat testosterone deficiency secondary to aging [7], may have beneficial effects in the setting of heart failure and ischemic heart disease $[4,8,9]$.

Despite the popularity of testosterone supplementation in older adults, how testosterone affects the heart is not fully understood. The discovery of androgen receptors in individual heart cells (myocytes) [10,11] suggests that testosterone might modulate heart function, at least in part, by effects on the ventricular myocytes themselves. Here, we review emerging evidence that suggests testosterone influences myocardial function at the cellular level by modifying processes involved in intracellular $\mathrm{Ca}^{2+}$ homeostasis. As disruption of $\mathrm{Ca}^{2+}$ handling plays a key role in many cardiovascular diseases $[12,13]$, understanding the mechanisms underlying the effects of testosterone 
on myocardial $\mathrm{Ca}^{2+}$ homeostasis may help explain its influence on cardiovascular health.

\section{Testosterone}

The principal male sex hormone, testosterone, is an androgen steroid. Testosterone plays important roles in normal growth and development, and its levels decline with age in both men and women. The following discussion provides a broad overview of testosterone, and its receptors, including pathways involved in its biosynthesis, regulation, and metabolism.

\section{Testosterone in men and women}

Testosterone is produced primarily by the testes in men, although it also can be produced by the adrenal glands and other sites including adipose tissue and bone [14,15]. It is responsible for testes descent and reproductive tract development in the fetus, development of male secondary sex characteristics in puberty, and the production of sperm $[16,17]$. Testosterone production in men begins in utero, rises sharply in puberty, and then declines with age $[17,18]$. Indeed, the Massachusetts Male Aging Study showed that total serum testosterone levels decline by $1.6 \%$ per year starting at age 40 [19]. Testosterone is also produced by the ovaries, the adrenal glands, and tissues such as adipose tissue and skin in women [6,15,20,21], although serum concentrations are almost 20-fold lower in pre-menopausal women compared to age-matched men [22]. Interestingly, testosterone levels also decline with age in women $[6,23]$. This age-dependent reduction in testosterone is not restricted to humans, as it is also seen in older male rats and mice ( $>20$ months of age) in conjunction with a decline in fertility $[24,25]$, although whether levels decline in aged female animals has not been investigated.

\section{Biosynthesis of testosterone}

Testosterone biosynthesis in men is controlled by the hypothalamic-pituitary-gonadal axis [26], as shown in the overview of major gonadal pathways for testosterone biosynthesis in Figure 1. The first step is the release of gonadotropin-releasing hormone (GnRH), which is synthesized and secreted from hypothalamic neurons [27]. GnRH binds to receptors on the anterior pituitary gland and stimulates the synthesis and secretion of luteinizing hormone (LH) into circulation [26,28]. LH binds to LH receptors on Leydig cells in the testes and stimulates a G-protein, $G_{s}$, to activate the cAMP/protein kinase A (PKA) pathway. This promotes the transport of cholesterol into the mitochondria and increases transcriptional activation of gene-encoding enzymes involved in testosterone biosynthesis [29]. The levels of testosterone in circulation are under tight hormonal regulation via a negative feedback mechanism that prevents the release of $\mathrm{GnRH}$ and $\mathrm{LH}$ when testosterone levels are high [26].

When serum testosterone levels are low, cholesterol in Leydig cells is transported to the inner mitochondrial membrane via a multi-protein complex in conjunction with the steroidogenic acute regulatory (StAR) protein [30], as shown in Figure 1. The rate-limiting reaction in the production of steroid hormones is the conversion of cholesterol to pregnenolone by the cholesterol side chain cleavage enzyme, a cytochrome P450 (CYP) enzyme known as CYP11A1 [30]. When pregnenolone is formed, it diffuses into the endoplasmic reticulum where testosterone biosynthesis proceeds via $\Delta^{4}$ and $\Delta^{5}$ pathways (Figure 1). In the $\Delta^{4}$ pathway, pregnenolone is converted to progesterone by $3 \beta$-hydroxysteroid dehydrogenase (HSD3 $\beta$ ) [15,31,32]. CYP17A1 converts progesterone to $17 \alpha$-hydroxyprogesterone by a hydroxylation reaction and then to androstenedione by a lysis reaction. Testosterone is formed by $17 \beta$-hydroxysteroid dehydrogenase 3 (HSD17 33). In the $\Delta^{5}$ pathway, CYP17A1 converts pregnenolone (via a hydroxylation reaction) to $17 \alpha-$ hydroxypregnenolone followed by a lysis reaction to yield dehydroepiandrosterone (DHEA) [15,31,32]. DHEA is then converted to androstenedione by HSD3 $\beta$. In the final step, HSD17 $\beta 3$ converts androstenedione to testosterone. DHEA can also be converted to androstenediol by HSD $17 \beta 3$ and then converted to testosterone by HSD3 $\beta$ $[15,31]$. Some testosterone is converted to the more potent androgen, dihydrotestosterone (DHT), by $5 \alpha-$ reductase [31]. In the Leydig cells, the major androgens (testosterone and DHT) leave by passive transport into circulation, where most bind to proteins including sex-hormone-binding globulin and/or albumin, although some circulate as free androgen [26].

Figure 1 also demonstrates that the enzyme aromatase can convert testosterone to the primary estrogen, 17ßestradiol. This is a minor pathway in the Leydig cell. Interestingly, aromatase also is present in a number of extragonadal sites including adipose tissue, bone, and the brain in both men and women [33]. Furthermore, cardiacspecific expression of aromatase has recently been shown in the adult mouse heart [34]. Conversion of circulating testosterone to $17 ß$-estradiol by these tissue-based aromatase pathways may increase $17 ß$-estradiol levels under conditions such as obesity [35]. Furthermore, certain anabolic steroids, including testosterone esters as well as nortestosterone derivatives (e.g., nandrolone decanoate and nandrolene phenpropionate), can be aromatized to estradiol [36]. Indeed, some anabolic steroid users take antiestrogens to minimize adverse effects (e.g., gynecomastia) associated with the aromatization of testosterone derivatives to estradiol [37]. Thus, effects of testosterone supplementation with derivatives that can be aromatized may actually be due, at least in part, to estradiol rather than 


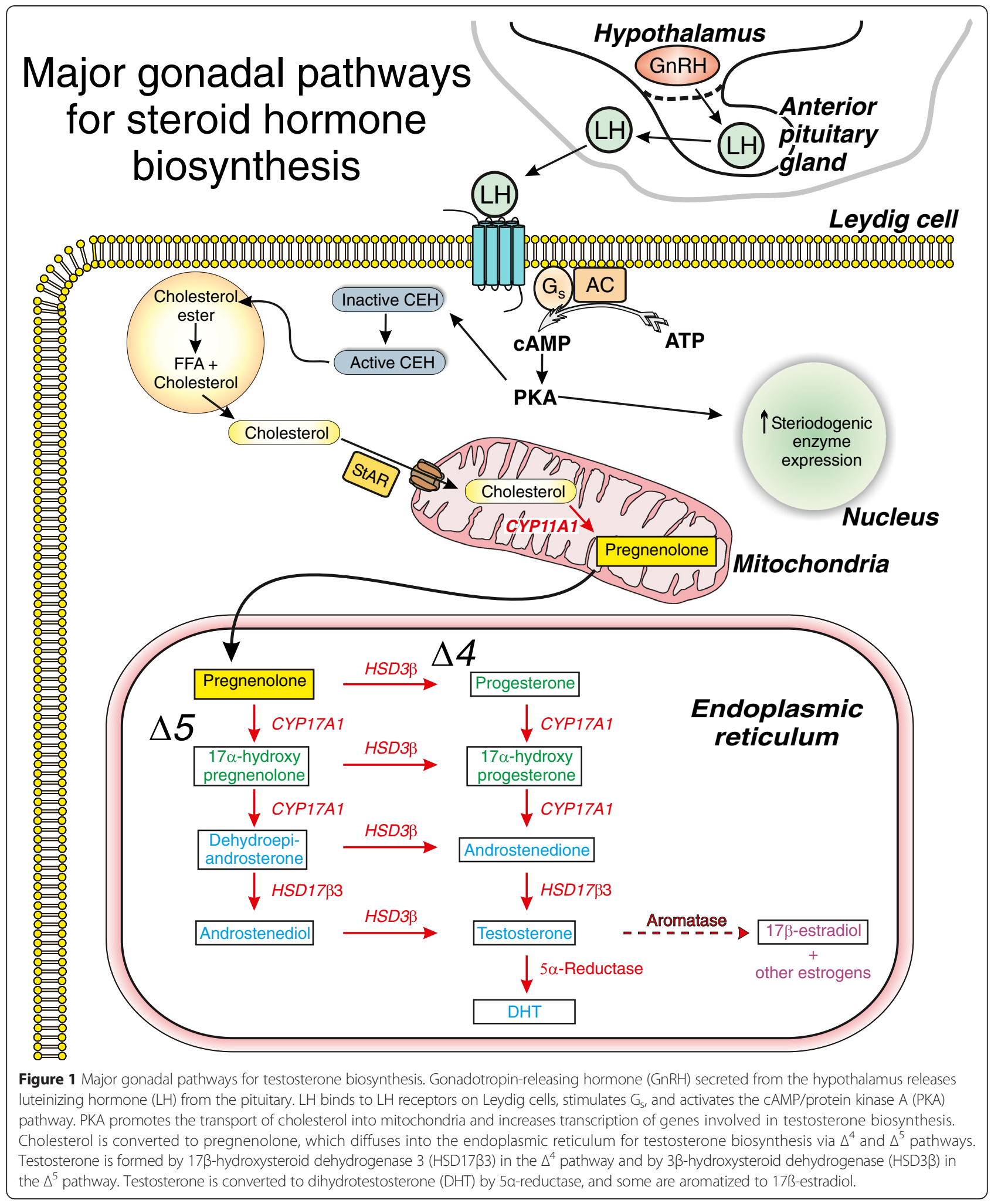

androgen. As a consequence, some studies of the effect of androgens on the cardiovascular system use the nonaromatizable androgen DHT, rather than testosterone or its derivatives, for example [38-40].
As discussed in the 'Testosterone in men and women' section, there is evidence that circulating testosterone decreases with age in both men and women $[6,18,19,23]$. In aging men, the fall in serum testosterone is largely 
due to a decrease in the ability of Leydig cells to produce testosterone in response to $\mathrm{LH}$ [41]. This arises as a result of age-associated attenuation of the cAMP/PKA pathway, leading to less transfer of cholesterol into the mitochondria and a reduction in the production of steroidogenic enzymes [41]. Interestingly, a similar mechanism has been proposed to lead to the age-dependent decrease in testosterone levels in male rats [42]. In women, the agedependent decline in circulating testosterone is thought to result from a combination of events including ovarian failure plus a reduction in the adrenal production of androgens [6]. Thus, the aging process reduces the amount of testosterone available to interact with androgen receptors, as described in the next section.

\section{Androgen receptors in the heart}

Biological effects of androgens are mediated by interactions with androgen receptors. The effects of androgens on androgen receptors associated with the male reproductive system are well documented [43]. The knowledge that these receptors are present in tissues such as the liver, kidney, brain, skeletal muscle, and heart $[10,44,45]$ has fueled interest in the role of androgens in regulation of physiological processes including myocardial function. Classic receptor-binding studies provided the first evidence for androgen receptors in the atria and ventricles of the heart $[46,47]$. Other studies showed that mRNA for the androgen receptor is present in cardiomyocytes isolated from men and women, as well as in cardiomyocytes from rats and dogs [10]. More recent work has shown that androgen receptor protein is expressed in both the atria and ventricles of male and female mice [11]. This latter study also shows that androgen receptors are predominantly expressed in the cytosol and nucleus of heart tissue from adult mice [11]. Together, these studies demonstrate that androgen receptors are present in the heart and raise questions about the role of testosterone in the regulation of myocardial function.

Most of the biological actions of endogenous and exogenous androgens are genomic effects mediated by androgen receptors that are members of the nuclear receptor gene superfamily. In the absence of androgens, the androgen receptor forms a complex with heat-shock proteins in the cytosol [43]. The binding of androgens causes receptor dissociation from heat-shock proteins and translocation to the nucleus, where the ligand-activated receptor homodimerizes and associates with chromatin by DNA-binding or through binding to other chromosomal proteins [43]. This causes transcriptional activation or repression of androgen-responsive genes, which are cell-specific according to transcription factors and cis-acting DNA elements in the particular tissue $[48,49]$. Transcriptional activation of androgen-responsive genes results in slow, long-lasting effects that can persist for hours after androgen receptor stimulation [50]. This androgenmediated transcriptional regulation is considered the canonical/genomic pathway for testosterone signaling and is thought to be responsible for most of the effects of androgens on the heart, as discussed in the 'Effects of testosterone on cardiac contractile function' section below.

While the classic genomic pathway mediates many of the biological effects of androgens, it is unlikely to be responsible for the rapid responses to androgens observed in some tissues, including the cardiovascular system. These transcription-independent effects are thought to be mediated by the activation of a nongenomic pathway, although the underlying molecular mechanisms are not well understood [43]. For example, there is strong evidence that testosterone induces rapid vasorelaxation in both large arteries and smaller resistance vessels [51]. Acute application of androgens also increases intracellular $\mathrm{Ca}^{2+}$ levels in osteoblasts, platelets, skeletal muscle cells, neurons, and, importantly, in cardiac myocytes [52]. Indeed, testosterone rapidly elicits voltage-dependent $\mathrm{Ca}^{2+}$ oscillations and $\mathrm{IP}_{3}$-receptor-mediated $\mathrm{Ca}^{2+}$ release from internal stores in neonatal rat cardiomyocytes [53]. While a cell-membraneassociated androgen receptor may be responsible, at present, its identity is unknown and other mechanisms, such as direct activation of ion channels and signaling pathways, may be involved $[43,51,52]$. Thus, although the canonical/genomic pathway is primarily responsible for the effects of androgens on the heart, the nongenomic pathway also may contribute.

\section{Effects of testosterone on cardiac contractile function Influence of androgens on myocardial contractility in humans}

Clinical studies have shown that there are male-female differences in the ability of the heart to contract, even in the absence of cardiovascular disease. For example, women have a higher ejection fraction at rest than men [54], but men respond to exercise with a greater increase in ejection fraction than women $[55,56]$. There is growing experimental evidence that estrogen plays a role in these male-female differences in myocardial contractility [57], although testosterone also may contribute.

The influence of androgens on myocardial contractility in humans has been investigated by examining the effects of anabolic-androgenic steroids on heart function. These steroids are synthetic derivatives of testosterone that are used therapeutically, in particular, to stimulate muscle growth [58]. They also are used as performanceenhancing drugs in sports, where their use is banned due to potential unfair advantage as well as adverse effects of high doses of these drugs [59]. While some echocardiography studies report that left ventricular mass is increased by anabolic steroid use [60-63], others report no 
effect [64-67], and the apparent increase in mass is abolished when it is indexed to fat-free body mass [68]. Echocardiography studies also have shown that anabolic steroid use adversely affects myocardial function, although again the data are not consistent. While some report that ejection fraction is attenuated by chronic anabolic steroid use $[60,68]$, others have found no change in ejection fraction in steroid users [61,63-66]. Similarly, although some studies report that anabolic steroid use slows cardiac relaxation [60-63,68], others report no effect [64-66]. These divergent results likely reflect the difficulties inherent in studies of anabolic steroid use. These include differences in drugs between and within studies, variations in the doses used and the difficulty in obtaining a precise history of drug use in participants. Nonetheless, these clinical studies provide evidence that testosterone may influence cardiac contractile function. This has been explored in more detail in pre-clinical models, as outlined below.

\section{The impact of testosterone on cardiac contractile function in animal models}

Various animal models have been used to investigate the influence of testosterone on myocardial function in vivo and in intact hearts. Some investigators have examined the influence of long-term supplementation with testosterone, or other androgens, on cardiac contractile function. However, most have inferred information about chronic testosterone effects from gonadectomy (GDX) experiments, where animals were subjected to bilateral removal of the testes ( \pm testosterone replacement) for varying periods of time. As discussed in detail below, results of these investigations demonstrate that male sex hormones modulate cardiac contractile function in animal models.

Relatively little is known about the influence of testosterone on cardiac contractile function in animal models in vivo, although one study has investigated the effect of GDX on myocardial structure and function with M-mode echocardiography [69]. These authors report that 10 weeks of hormone deprivation attenuates contractile function, as demonstrated by a decrease in both fractional shortening and ejection fraction compared to hormone-replete control mice [69]. GDX also causes concentric remodeling of the heart, characterized by increased left ventricular posterior wall and reduced left ventricular internal diameter in diastole, as well as increased relative wall thickness when compared to intact males [69]. These echocardiographic data suggest that prolonged absence of male sex hormones modifies the structure and function of the heart. Still, whether this affects cardiac relaxation and promotes diastolic dysfunction has not yet been investigated with techniques such as tissue Doppler. Such studies would be of considerable interest, as there is evidence that GDX slows relaxation in intact hearts and in isolated myocytes, as discussed below.

A number of studies have explored the effects of testosterone supplementation on myocardial contractility in intact hearts isolated from various animal models. These studies typically used various anabolic-androgenic steroids at high doses to mimic anabolic steroid abuse in exercise training. Most found that chronic administration (8-12 weeks) of 5-50 mg/kg/week of anabolic steroid (e.g., nandrolone decanoate, stanozolol, or $17 \alpha$-methyltestosterone) suppresses peak left ventricular contractile performance in young adult rats ([70-72] but c.f. [73]). By contrast, high doses of anabolic steroids have no effect on the rates of left ventricular pressure rise $(+\mathrm{dP} / \mathrm{dT})$ or the rates of left ventricular pressure decay $(-\mathrm{dP} / \mathrm{dT})$, which indicates that these agents do not affect the time course of contraction or relaxation $([70,71,73]$ but $c . f$. $[72])$. The impact of more physiological steroid concentrations also has been examined. Eleawa et al. [74] treated young intact rats with concentrations of testosterone propionate $(1.5 \mathrm{mg} / \mathrm{kg} /$ week; 12 weeks) designed to produce plasma testosterone levels between 3-11 ng/ml, to mimic more physiological concentrations. They found that these lower levels of testosterone had no effect on left ventricular developed pressure (LVDP), $+\mathrm{dP} / \mathrm{dT}$, or $-\mathrm{dP} / \mathrm{dT}$ in Langendorff-perfused hearts [74]. These observations indicate that while high levels of anabolic-androgenic steroids can negatively affect peak cardiac contractile performance, lower concentrations have few effects in animal models.

Other investigators have examined the influence of chronic testosterone withdrawal on cardiac contractility in GDX rodents, as summarized in Table 1. Studies in Langendorff-perfused hearts show that LVDP is not affected by short-term (2-9 weeks) GDX [75,76], but declines after longer-term GDX (e.g., 16 weeks) [74]. There is evidence that these deficits in contractile function in low-testosterone states may be more prominent at high physiological loads (Table 1). For example, LVDP is attenuated 3-10 weeks after GDX in working hearts models, but only when hearts are exposed to high left atrial pressures [77,78]. Furthermore, although left ventricular end-diastolic pressure (LVEDP) is unaffected by GDX in Langendorff-perfused [75] and catheterized hearts [69], it declines when GDX hearts are subjected to high left atrial pressures $[77,78]$. The time course of contraction is also modified by withdrawal of male hormones (Table 1 ). While most studies report that $+\mathrm{dP} / \mathrm{dT}$ is not affected by GDX $([69,76]$ but $c . f$. [74] $)$, there is evidence that $-\mathrm{dP} / \mathrm{dT}$ is slowed following GDX $([74,77,78]$ but c.f. $[69,76])$. Consistent with these results, recent work has shown that $+\mathrm{dP} / \mathrm{dT}$ is also slower in young adult male mice that overexpress aromatase and have much lower testosterone levels (and higher estrogen levels) compared to wild type controls [79]. Interestingly, these changes in the 
Table 1 Influence of chronic testosterone withdrawal on myocardial contractility

\begin{tabular}{|c|c|c|c|c|c|}
\hline Component & Model & Functional change & Duration of GDX (weeks) & Species & Reference \\
\hline \multirow[t]{5}{*}{ LVDP } & Langendorff & $\leftrightarrow$ & 2 & Rat & [75] \\
\hline & & $\leftrightarrow$ & 9 & Rat & {$[76]$} \\
\hline & & ${ }^{\mathrm{a}} \downarrow$ & 16 & Rat & [74] \\
\hline & Working heart & $b_{\downarrow}$ & 3 & Rat & {$[77]$} \\
\hline & & $b_{\downarrow}$ & 10 & Rat & [78] \\
\hline \multirow[t]{4}{*}{ LVEDP } & Millar catheterization & $\leftrightarrow$ & $10-11$ & Mouse & {$[69]$} \\
\hline & Langendorff & $\leftrightarrow$ & 2 & Rat & [75] \\
\hline & Working heart & ${ }^{b} \downarrow$ & 3 & Rat & [77] \\
\hline & & ${ }^{b} \downarrow$ & 10 & Rat & [78] \\
\hline \multirow[t]{3}{*}{$+\mathrm{dP} / \mathrm{dT}$} & Millar catheterization & $\leftrightarrow$ & $10-11$ & Mouse & [69] \\
\hline & Langendorff & $\leftrightarrow$ & 9 & Rat & {$[76]$} \\
\hline & & ${ }^{a} \downarrow$ & 16 & Rat & [74] \\
\hline \multirow[t]{5}{*}{$-d P / d T$} & Millar catheterization & $\leftrightarrow$ & $10-11$ & Mouse & [69] \\
\hline & Langendorff & $\leftrightarrow$ & 9 & Rat & [76] \\
\hline & & ${ }^{a} \downarrow$ & 16 & Rat & [74] \\
\hline & Working heart & $b_{\downarrow}$ & 3 & Rat & [77] \\
\hline & & ${ }^{b} \downarrow$ & 10 & Rat & [78] \\
\hline
\end{tabular}

${ }^{\mathrm{a} E f f e c t}$ of GDX is reversed by testosterone replacement. ${ }^{\mathrm{b}}$ Functional change in the working heart model was only observed at high left atrial pressures.

amplitude and time course of cardiac contraction in hearts from GDX animals are reversed by testosterone replacement [74]. Together, these observations suggest that chronic testosterone withdrawal attenuates peak contraction and slows relaxation, especially when hearts are working under high loads. As cardiac contraction is initiated by a transient rise in cytosolic $\mathrm{Ca}^{2+}$ in individual cardiomyocytes, effects of testosterone on contractile function may arise from effects on mechanisms involved in intracellular $\mathrm{Ca}^{2+}$ handling, as discussed below.

Long-term influence of testosterone on cellular $\mathrm{Ca}^{2+}$ handling The process by which cardiac excitation triggers a rise in intracellular $\mathrm{Ca}^{2+}$ and contraction is known as excitationcontraction coupling (reviewed by $[80,81]$ ). This process is initiated when $\mathrm{Ca}^{2+}$ enters the cell via L-type $\mathrm{Ca}^{2+}$ channels during phase 2 of the action potential (AP). This small influx of $\mathrm{Ca}^{2+}$ triggers the release of a much larger amount of $\mathrm{Ca}^{2+}$ through $\mathrm{Ca}^{2+}$ release channels (ryanodine receptors (RyRs)) in the sarcoplasmic reticulum (SR) in a process known as $\mathrm{Ca}^{2+}$-induced $\mathrm{Ca}^{2+}$ release $[12,81] . \mathrm{Ca}^{2+}$ is released from the SR in the form of discrete, subcellular units called $\mathrm{Ca}^{2+}$ sparks that fuse to form the $\mathrm{Ca}^{2+}$ transient [82]. $\mathrm{Ca}^{2+}$ then binds to contractile proteins, known as myofilaments, which results in sarcomere shortening and cardiac contraction. Relaxation occurs when $\mathrm{Ca}^{2+}$ is taken back up into the SR by the sarco/endoplasmic reticulum $\mathrm{Ca}^{2+}$-ATPase (SERCA), whose activity is regulated by the endogenous inhibitor, phospholamban (PLB). Some $\mathrm{Ca}^{2+}$ is also removed from the cell on a beat-to-beat basis, primarily by the bidirectional $\mathrm{Na}^{+} / \mathrm{Ca}^{2+}$ exchanger (NCX) that removes one $\mathrm{Ca}^{2+}$ in exchange for $3 \mathrm{Na}^{+}$[83]. The effects of testosterone on cardiac contractile function may arise through effects on components of the excitationcontraction coupling pathway at the level of the myocyte.

\section{Testosterone and the cardiac action potential}

As $\mathrm{SR} \mathrm{Ca}^{2+}$ release and contraction are initiated by the cardiac AP, some investigators have explored the influence of testosterone on AP properties (Table 2). Chronic exposure to testosterone itself has no effect on resting membrane potential (RMP), AP amplitude, or AP duration at $50 \%$ repolarization $\left(\mathrm{APD}_{50}\right)$ but actually prolongs $\mathrm{APD}_{95}$ in rat papillary muscle [84]. By contrast, more recent work in isolated mouse ventricular myocytes has shown that, while chronic DHT treatment has no effect on RMP, it does cause a marked abbreviation of both $\mathrm{APD}_{50}$ and $\mathrm{APD}_{90}$ [39]. One factor that might account for discrepancies between these two studies is the difference between chronic exposures to testosterone versus DHT. As reviewed in the 'Biosynthesis of testosterone' section, testosterone can be converted to estrogen by the enzyme aromatase whereas DHT cannot $[33,36]$. Therefore, estrogen may contribute to observed effects in studies where testosterone is used as the androgen receptor ligand [84]. Consistent with this idea, chronic exposure to estrogen has been shown to prolong APD in some models [57], in particular, when animals are in the estrus stage where estrogen levels peak [85-87]. Thus, apparent prolongation of APD by testosterone may be due to estradiol produced by 
Table 2 Impact of chronic androgen treatment and GDX on resting and action potentials

\begin{tabular}{|c|c|c|c|c|c|c|}
\hline${ }^{\mathrm{a} C o m p o n e n t}$ & Treatment & Duration (weeks) & Preparation & Functional change & Species & Reference \\
\hline \multicolumn{7}{|c|}{ Testosterone supplementation } \\
\hline \multirow[t]{2}{*}{ RMP } & ${ }^{\mathrm{b}}$ Testosterone & 4 & Ventricular muscle & $\leftrightarrow$ & Rat & [84] \\
\hline & ${ }^{\mathrm{C}}$ Dihydrotestosterone & 13 & Ventricular myocyte & $\leftrightarrow$ & Mouse & [39] \\
\hline AP amplitude & ' Testosterone & 4 & Ventricular muscle & $\leftrightarrow$ & Rat & [84] \\
\hline \multirow[t]{2}{*}{ APD50 } & bTestosterone & 4 & Ventricular muscle & $\leftrightarrow$ & Rat & {$[84]$} \\
\hline & ${ }^{c}$ Dihydrotestosterone & 13 & Ventricular myocyte & $\downarrow$ & Mouse & [39] \\
\hline \multirow[t]{2}{*}{ APD90/95 } & ${ }^{\mathrm{b}}$ Testosterone & 4 & Ventricular muscle & $\uparrow$ & Rat & [84] \\
\hline & ${ }^{c}$ Dihydrotestosterone & 13 & Ventricular myocyte & $\downarrow$ & Mouse & [39] \\
\hline \multicolumn{7}{|c|}{ Gonadectomy (GDX) } \\
\hline \multirow[t]{2}{*}{ RMP } & GDX & 4 & Ventricular muscle & $\leftrightarrow$ & Rat & {$[84]$} \\
\hline & & $11-15$ & Ventricular myocyte & $\leftrightarrow$ & Mouse & [39] \\
\hline AP amplitude & GDX & 4 & Ventricular muscle & $\leftrightarrow$ & Rat & {$[84]$} \\
\hline \multirow[t]{2}{*}{ APD50 } & GDX & 4 & Ventricular muscle & $\uparrow$ & Rat & {$[84]$} \\
\hline & & $11-15$ & Ventricular myocyte & $\uparrow$ & Mouse & [39] \\
\hline \multirow[t]{2}{*}{ APD90/95 } & GDX & 4 & Ventricular muscle & $\leftrightarrow$ & Rat & [84] \\
\hline & & $11-15$ & Ventricular myocyte & $\uparrow$ & Mouse & [39] \\
\hline
\end{tabular}

${ }^{\mathrm{a}}$ All experiments used paced tissues and myocytes from male animals only. ${ }^{\mathrm{b}}$ Testosterone treatment with $5 \mathrm{mg} / \mathrm{kg} / \mathrm{day} .{ }^{\mathrm{c}}$ Dihydrotestosterone treatment with a 7.5-mg pellet.

aromatization. Certainly the DHT data [39] suggest that chronic exposure to androgens actually abbreviates APD.

Information about the effects of testosterone on the cardiac AP also has been inferred from studies where animals were subjected to bilateral GDX through removal of the testes. The results of these investigations also are summarized in Table 2. It seems clear that GDX has no effect on either RMP or AP amplitude [39,84]. By contrast, there is general agreement that GDX prolongs $\mathrm{APD}_{50}$ $[39,84]$ and $\mathrm{APD}_{90 / 95}$ ([39] but c.f. [84]) in both intact ventricular muscle and in isolated ventricular myocytes (Table 2). Taken together with the DHT work reviewed above, these observations suggest that chronic exposure to testosterone abbreviates the cardiac AP, and in its absence, APD is prolonged. The shape of the cardiac AP is inextricably linked to $\mathrm{SR} \mathrm{Ca}^{2+}$ release and contraction [85]. Thus, the increase in APD seen following GDX may prolong $\mathrm{SR} \mathrm{Ca}^{2+}$ release, increase the duration of contraction, and slow relaxation. Thus, prolongation of the AP may help explain the prolonged relaxation times seen in the hearts of GDX animals (Table 1).

The influence of testosterone on transarcolemmal ion fluxes GDX may act to prolong the cardiac AP by modifying ionic currents to either attenuate repolarization or prolong depolarization. Therefore, a number of investigators have examined the influence of GDX on sarcolemmal proteins and currents, as shown in Table 3. Most studies have examined repolarizing $\mathrm{K}^{+}$currents in rodent models 13 to 16 weeks after GDX (Table 3). There is general agreement that GDX has no effect on transient outward current $\left(\mathrm{I}_{\mathrm{TO}}\right)$, steady state $\mathrm{K}^{+}$current $\left(\mathrm{I}_{\mathrm{SS}}\right)$ and inward rectifier $\mathrm{K}^{+}$current $\left(\mathrm{I}_{\mathrm{K} 1}\right)$, or on the expression of proteins or mRNA levels linked to these currents $[38,74]$. By contrast, GDX reduces the magnitude of the ultrarapid delayed rectifier $\mathrm{K}^{+}$current $\left(\mathrm{I}_{\mathrm{Kur}}\right)$ and decreases the expression of the corresponding Kv1.5 protein ([38] but c.f. [74]). This reduction in peak $\mathrm{I}_{\mathrm{Kur}}$ could contribute to the prolongation of the APD in rodent models. In the rabbit model, where the slow delayed rectifier $\mathrm{K}^{+}$ current $\left(\mathrm{I}_{\mathrm{Ks}}\right)$ is the major repolarizing current [88], peak $\mathrm{I}_{\mathrm{Ks}}$ also is slightly reduced by GDX [89]. These observations suggest that long-term testosterone withdrawal attenuates repolarizing currents, which may help explain the longer APs seen in cardiac muscle and myocytes from GDX animals.

Prolongation of the AP by GDX also could arise through changes in ionic currents that prolong depolarization. Whether $\mathrm{Na}^{+}$currents are influenced by GDX has not yet been investigated. However, a few studies have investigated the effect of GDX on L-type $\mathrm{Ca}^{2+}$ current $\left(\mathrm{I}_{\mathrm{Ca}-\mathrm{L}}\right)$, as shown in Table 3. Voltage-clamp studies show that GDX has no effect on peak $\mathrm{I}_{\mathrm{Ca}-\mathrm{L}}$, at least in the rabbit model [40]. By contrast, the density of 1,4-dihydropyridine (DHP) receptors (L-type $\mathrm{Ca}^{2+}$ channels) is markedly reduced by GDX in hearts from male rodents, and this effect is reversed by testosterone replacement $[90,91]$. This suggests that GDX may actually reduce $\mathrm{Ca}^{2+}$ influx in the heart. In support of this, peak L- and T-type $\mathrm{Ca}^{2+}$ currents are enhanced in neonatal rat cardiomyocytes 
Table 3 Influence of gonadectomy on sarcolemmal proteins and currents

\begin{tabular}{|c|c|c|c|c|c|}
\hline Component & Treatment & Duration (weeks) & Functional change & Species & Reference \\
\hline \multirow[t]{3}{*}{ Ultra-rapid delayed rectifier K+ current (IKur) } & ${ }^{\mathrm{a} G D X}$ & 13 & $\downarrow$ peak $I_{\text {Kur }}$ & Mouse & {$[38,39]$} \\
\hline & & 13 & $\downarrow$ Kv1.5 protein & Mouse & {$[38,39]$} \\
\hline & GDX & 16 & $\leftrightarrow \mathrm{Kv} 1.5$ protein & Rat & [74] \\
\hline \multirow[t]{2}{*}{ Transient outward K+ current (ITO) } & GDX & 13 & $\leftrightarrow$ peak ITO & Mouse & {$[38]$} \\
\hline & & 13 & $\leftrightarrow \mathrm{Kv} 4.2 / 4.3$ protein & Mouse & {$[38]$} \\
\hline \multirow[t]{2}{*}{ Steady state K+ current (ISS) } & GDX & 13 & $\leftrightarrow$ peak $I_{\text {sS }}$ & Mouse & {$[38]$} \\
\hline & & 13 & $\leftrightarrow \mathrm{Kv} 1.2$ protein & Mouse & {$[38]$} \\
\hline \multirow[t]{5}{*}{ Inward rectifier K+ current (IK1) } & GDX & 13 & $\leftrightarrow$ peak $I_{\mathrm{K} 1}$ & Mouse & {$[38]$} \\
\hline & & 13 & $\leftrightarrow$ Kir2.1 protein & Mouse & {$[38]$} \\
\hline & & 16 & $\downarrow$ Kir2.1 mRNA & Rat & [74] \\
\hline & & 16 & $\leftrightarrow$ Kir2.2 mRNA & Rat & [74] \\
\hline & & 16 & $\leftrightarrow$ Kir2.3 mRNA & Rat & [74] \\
\hline Slow delayed rectifier K+ current (IKs) & GDX & 8 & $\downarrow$ peak $I_{\mathrm{Ks}}$ & Rabbit & {$[89]$} \\
\hline \multirow[t]{3}{*}{ L-type Ca2+ current (ICa-L)/ dihydropyridine receptor (DHPR) } & GDX & 9 & $\leftrightarrow$ peak $I_{\text {Ca-L }}$ & Rabbit & [40] \\
\hline & ${ }^{b} G D X$ & 2 & $\downarrow$ DHPR mRNA & Rat & [90] \\
\hline & & 16 & $\downarrow$ DHPR mRNA & Rat & [91] \\
\hline \multirow[t]{7}{*}{$\mathrm{Na}+-\mathrm{Ca} 2+$ exchanger } & GDX & 10 & $\leftrightarrow$ NCX activity & Rat & [96] \\
\hline & & 9 & $\leftrightarrow$ NCX activity & Rat & [76] \\
\hline & & 2 & $\leftrightarrow$ NCX protein & Rat & [75] \\
\hline & & 10 & $\downarrow N C X$ protein & Rat & [96] \\
\hline & & $10-11$ & $\uparrow \mathrm{NCX}$ protein & Mouse & [69] \\
\hline & ${ }^{b} G D X$ & 2 & $\downarrow N C X$ mRNA & Rat & [90] \\
\hline & & 16 & $\downarrow N C X$ mRNA & Rat & [91] \\
\hline
\end{tabular}

${ }^{a}$ Indicates that the effect of GDX was reversed by treatment with dihydrotestosterone. ${ }^{b}$ Indicates that the effect of GDX was reversed by treatment with testosterone.

chronically exposed to testosterone (24-30 h in culture), an effect blocked by the nuclear androgen receptor antagonist, flutamide [92,93]. Chronic exposure to DHT also increases peak $\mathrm{I}_{\mathrm{Ca}-\mathrm{L}}$ and increases the expression of $\mathrm{Ca}_{\mathrm{v}} 1.2$ (the pore-forming subunit of the L-channel) in cultured human ventricular myocytes [94]. These findings suggest that testosterone increases inward $\mathrm{Ca}^{2+}$ currents and that this effect is attenuated by GDX. Thus, $\mathrm{Ca}^{2+}$ influx may actually be inhibited by GDX, so enhanced $\mathrm{Ca}^{2+}$ influx does not account for the increase in APD observed in the GDX heart. On the other hand, $\mathrm{Ca}^{2+}$ influx via $\mathrm{I}_{\mathrm{Ca}-\mathrm{L}}$ is the primary trigger for $\mathrm{SR} \mathrm{Ca}^{2+}$ release. Thus, effects of testosterone on $\mathrm{I}_{\mathrm{Ca}-\mathrm{L}}$ could have important effects on cardiac contractility as discussed in the next section.

Another important sarcolemmal protein that regulates intracellular $\mathrm{Ca}^{2+}$ levels is NCX. This exchanger primarily operates to remove one $\mathrm{Ca}^{2+}$ from the cell in exchange for three $\mathrm{Na}^{+}$[95]. This generates an inward current that helps maintain the AP plateau [95] and could, in theory, help prolong APD in GDX. Whether NCX is modified by testosterone has been investigated in GDX rodents with biochemical and molecular approaches (Table 3). While several studies have shown that NCX activity and protein expression are unchanged 2 to 10 weeks after GDX $[75,76,96]$, others report that NCX protein levels are reduced ([96] but c.f. [69]). There is also evidence that mRNA levels decline after both short-term (2 weeks) and long-term (16 weeks) GDX, and this effect is abolished by testosterone supplementation $[90,91]$, as shown in Table 3. As NCX helps remove $\mathrm{Ca}^{2+}$ from the cell, a reduction in NCX in GDX hearts could slow relaxation, as observed in perfused hearts from GDX animals (Table 1). Still, at present, there is no consensus on the effect of GDX on NCX, and it is uncertain whether NCX helps prolong the APD.

\section{Testosterone affects contractions and $\mathrm{Ca}^{2+}$ release in individual cardiomyocytes}

Previous experimental studies have shown that chronic testosterone withdrawal attenuates cardiac contractility in vivo (the 'The impact of testosterone on cardiac contractile function in animal models' section). GDX also reduces peak contraction and slows relaxation in isolated perfused hearts, especially when hearts are working under high loads (the 'The impact of testosterone on cardiac contractile function in animal models' section; 
Table 1). These changes in cardiac contractile function could arise, in part, because the ability of individual ventricular myocytes to contract is modified by testosterone. For example, there is some evidence that cardiomyocyte contractions are larger in cells from male animals when compared to females (reviewed by [57]). Furthermore, chronic testosterone treatment ( $24 \mathrm{~h}$ in culture) enhances peak contractions, measured as unloaded cell shortening, in isolated rat cardiomyocytes [97]. Larger contractions are also observed in cells from female aromatase knockout mice, who have elevated testosterone levels along with low-estrogen levels [98]. Studies in myocytes from GDX rats also provide some support for these observations (Table 4). While one investigation showed that peak contractions are not affected by GDX [91], another found that peak responses are attenuated by testosterone deprivation [99]. On balance, these studies suggest that testosterone enhances peak contraction and testosterone deprivation may suppress contraction at the level of the cardiomyocyte.

Other studies have investigated the influence of testosterone on the rate of relaxation of contraction. There is evidence that the rates of relaxation are faster in cardiomyocytes from male animals than in cells from females (reviewed by [57]). Likewise, chronic exposure to testosterone ( $24 \mathrm{~h}$ in culture) increases the rate of relaxation in individual rat myocytes [97], while testosterone withdrawal slows cardiomyocyte relaxation [91,99], as shown in Table 4. Female aromatase knockout mice (with high testosterone and low estrogen) also exhibit faster contractions than wild type controls [98]. These findings suggest that the slower $-\mathrm{dP} / \mathrm{dT}$ reported in many studies of perfused GDX hearts $([74,77,78]$ but c.f. $[69,76])$ is attributable, at least in part, to prolongation of contraction at the cellular level.

Testosterone could modify cardiac contractile function by effects on the contractile proteins themselves. However, few studies have examined the impact of testosterone on myofilament proteins. One study has shown that testosterone deprivation has no effect on myofilament $\mathrm{Ca}^{2+}$ sensitivity but reduces maximal myofilament responses to $\mathrm{Ca}^{2+}$ in skinned rat ventricular muscle [96]. This decrease in maximal responsiveness to $\mathrm{Ca}^{2+}$ could contribute to the reduction in contractility observed in GDX hearts. Another study has examined myosin heavy chain (MHC) composition in sham-operated and GDX rat hearts [100]. They found that GDX causes a shift from the fast $\alpha-\mathrm{MHC}$ isoform to the slower $\beta-\mathrm{MHC}$ isoform, and this is reversed by testosterone replacement [100]. Predominance of the slower $\mathrm{B}-\mathrm{MHC}$ isoform could contribute to the slowing of relaxation in isolated cardiomyocytes and perfused hearts from GDX animals.

Others have investigated whether the influence of testosterone on cardiac contraction is mediated by changes in underlying $\mathrm{Ca}^{2+}$ transients (Table 4). There is some evidence that $\mathrm{Ca}^{2+}$ transients are larger and, in particular, faster in myocytes from males than females (reviewed by [57]). Female aromatase knockout mice (high-testosterone and low-estrogen levels) also exhibit larger and faster $\mathrm{Ca}^{2+}$ transients when compared to wild type [98]. Furthermore, although one study showed that $\mathrm{Ca}^{2+}$ transients are not affected by GDX [76], another reported that peak responses are attenuated by GDX [99]. As with myocyte contraction, there is general agreement (Table 4) that GDX slows the rate of decay of the $\mathrm{Ca}^{2+}$ transient in isolated cardiomyocytes $[76,99]$. These findings suggest that the smaller, slower contraction characteristic of GDX myocytes and hearts are attributable, at least in part, to changes in the underlying $\mathrm{Ca}^{2+}$ transients.

Interestingly, studies that report no change in peak contractions and $\mathrm{Ca}^{2+}$ transients after GDX [76,91] use external $\mathrm{Ca}^{2+}$ concentrations and pacing frequencies far below physiological for rats (e.g., $1 \mathrm{mM} \mathrm{Ca}^{2+} ; 0.2-$ $0.5 \mathrm{~Hz}$ ). By contrast, Curl et al. [99], who also used lowpacing rates (e.g., $0.5 \mathrm{~Hz}$ ), used a range of external $\mathrm{Ca}^{2+}$ concentrations (e.g., $0.5-2 \mathrm{mM}$ ) and found that peak contractions and $\mathrm{Ca}^{2+}$ transients declined after GDX, especially at higher external $\mathrm{Ca}^{2+}$ concentrations (Table 4). These data suggest that the influence of GDX on peak cardiac contraction may become evident when cardiomyocytes are working under more physiological conditions. As

Table 4 Gonadectomy modifies cardiomyocyte $\mathrm{Ca}^{2+}$ release and contraction

\begin{tabular}{|c|c|c|c|c|c|c|c|}
\hline Parameter & Component & Functional change & {$\left[\mathrm{Ca}^{2+}\right](\mathrm{mM})$} & Pacing rate $(\mathrm{Hz})$ & Duration of GDX (weeks) & Species & Reference \\
\hline \multirow[t]{4}{*}{ Cell shortening } & Peak contraction & $\leftrightarrow$ & 1 & 0.5 & 16 & Rat & [91] \\
\hline & & ${ }^{a} \downarrow$ & $0.5-2$ & 0.5 & 2 & Rat & [99] \\
\hline & Relaxation rate & aslowed & 1 & 0.5 & 16 & Rat & [91] \\
\hline & & & $0.5-2$ & 0.5 & 2 & Rat & [99] \\
\hline \multirow[t]{4}{*}{ Intracellular Ca2+ } & Peak $\mathrm{Ca}^{2+}$ transient & $\leftrightarrow$ & 1 & 0.2 & 9 & Rat & {$[76]$} \\
\hline & & ${ }^{a} \downarrow$ & $0.5-2$ & 0.5 & 2 & Rat & [99] \\
\hline & $\mathrm{Ca}^{2+}$ transient decay rate & ${ }^{\mathrm{a}}$ Slowed & $0.5-2$ & 0.5 & 2 & Rat & [99] \\
\hline & & & 1 & 0.2 & 9 & Rat & [76] \\
\hline
\end{tabular}

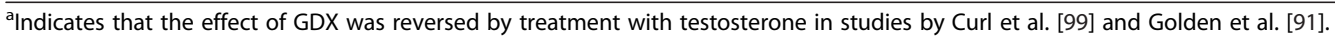


the impact of GDX on contractility in perfused hearts is greatest when hearts are working at high loads [77,78], experiments that expose GDX myocytes to higher pacing frequencies could be informative.

In theory, testosterone may modulate other aspects of $\mathrm{Ca}^{2+}$ handling in the cardiomyocyte. For example, whether the rate of rise of the $\mathrm{Ca}^{2+}$ transient is modified by GDX has not yet been investigated. Changes in the $\mathrm{Ca}^{2+}$ transient rise time in GDX hearts could reflect desynchrony of $\mathrm{Ca}^{2+}$ release mechanisms in the SR [101]. Furthermore, whether diastolic $\mathrm{Ca}^{2+}$ levels are modified by testosterone has not been examined. Higher diastolic $\mathrm{Ca}^{2+}$ levels would be expected if SR $\mathrm{Ca}^{2+}$ sequestration is slowed by GDX, as suggested by the longer $\mathrm{Ca}^{2+}$ transient decay rates seen in cells from GDX animals $[76,99]$. The next section reviews studies that have investigated the influence of chronic testosterone withdrawal on specific intracellular $\mathrm{Ca}^{2+}$-handling mechanisms in the heart.

\section{Testosterone targets $\mathrm{SR} \mathrm{Ca}^{2+}$-handling mechanisms in the cardiomyocyte}

The SR plays a crucial role in $\mathrm{Ca}^{2+}$ release and reuptake within the cardiomyocyte, so a number of investigators have examined the influence of testosterone on SR $\mathrm{Ca}^{2+}$ release mechanisms (Table 5). As with most studies, the influence of testosterone on processes involved in SR $\mathrm{Ca}^{2+}$ handling has largely been inferred from studies done on animals subjected to GDX. Although there is no indication that RyR protein levels are affected by GDX [75], RyR-mediated ${ }^{45} \mathrm{Ca}^{2+}$ flux is actually reduced following GDX in the rat model [76]. In support of this observation, chronic exposure to testosterone (24-30 h of culture) increases the amplitude of subcellular $\mathrm{SR} \mathrm{Ca}^{2+}$ release units known as $\mathrm{Ca}^{2+}$ sparks [92]. Furthermore, $\mathrm{Ca}^{2+}$ sparks are larger in cardiomyocytes from male animals when compared to females [102,103]. Taken together, these findings suggest that testosterone enhances $\mathrm{SR} \mathrm{Ca}^{2+}$ release by increasing the magnitude of individual $\mathrm{Ca}^{2+}$ sparks and that chronic testosterone withdrawal suppresses this process. If $\mathrm{SR} \mathrm{Ca}^{2+}$ release events are reduced by GDX, this could account for the reduction in peak contraction observed in both intact hearts and cardiomyocytes from GDX animals. Additional studies that explore the role of testosterone in regulating $\mathrm{Ca}^{2+}$ sparks via signaling pathways such as those mediated by PKA and $\mathrm{Ca}^{2+}$ calmodulin-dependent kinase II (CaMKII) [102,104,105] would be of interest.

Most investigations of the influence of testosterone on SR function have focussed on its effects on $\mathrm{SR} \mathrm{Ca}^{2+}$ content and $\mathrm{SR} \mathrm{Ca}^{2+}$ reuptake mechanisms. Studies have shown that levels of the $\mathrm{SR} \mathrm{Ca}^{2+}$-binding proteins calsequestrin and calreticulin are not affected by GDX [69]. However, SR $\mathrm{Ca}^{2+}$ content is reduced in myocytes from GDX animals when compared to sham-operated controls [76]. The mechanism responsible for the reduction in $\mathrm{SR} \mathrm{Ca}^{2+}$ content in the setting of chronic testosterone withdrawal has been investigated. Table 5 shows that the

Table 5 Effect of gonadectomy on $\mathrm{Ca}^{2+}$ handling by the sarcoplasmic reticulum

\begin{tabular}{|c|c|c|c|c|}
\hline Component & Functional change & Duration of GDX (weeks) & Species & Reference \\
\hline \multirow[t]{2}{*}{ SR Ca2+ release } & $\leftrightarrow$ RyR2 protein & 2 & Rat & {$[75]$} \\
\hline & ${ }^{\mathrm{a}} \downarrow$ RyR-mediated ${ }^{45} \mathrm{Ca}^{2+}$ flux & 9 & Rat & [76] \\
\hline \multirow[t]{3}{*}{ SR Ca2ccps stores } & $\leftrightarrow$ Calsequestrin protein & $10-11$ & Mouse & {$[69]$} \\
\hline & $\leftrightarrow$ Calreticulin protein & 10-11 & Mouse & [69] \\
\hline & ${ }^{a} \downarrow S R \mathrm{Ca}^{2+}$ content & 9 & Rat & [76] \\
\hline \multirow[t]{5}{*}{ SERCA2a } & $\leftrightarrow$ SERCA2a protein & 2 & Rat & {$[75]$} \\
\hline & & 10 & Rat & [96] \\
\hline & & 10-11 & Mouse & [69] \\
\hline & $\leftrightarrow$ SERCA activity & 10 & Rat & {$[76]$} \\
\hline & ${ }^{a} \downarrow$ SERCA activity & 9 & Rat & [96] \\
\hline \multirow[t]{8}{*}{ PLB } & $\leftrightarrow$ PLB protein & 2 & Rat & {$[75]$} \\
\hline & & 10 & Rat & {$[96]$} \\
\hline & & 9 & Rat & {$[76]$} \\
\hline & & 10-11 & Mouse & {$[69]$} \\
\hline & ${ }^{a} \downarrow$ PLB Thr ${ }^{17}$ phosphorylation & $10-11$ & Mouse & [69] \\
\hline & & 10 & Rat & {$[96]$} \\
\hline & $\downarrow$ PLB Ser ${ }^{16}$ phosphorylation & 10-11 & Mouse & [69] \\
\hline & $\leftrightarrow$ PLB Ser ${ }^{16}$ phosphorylation & 10 & Rat & {$[96]$} \\
\hline
\end{tabular}

${ }^{a}$ Indicates that the effect of GDX was reversed by treatment with testosterone in studies by Tsang et al. [76] and Witayavanitkul et al. [96]. 
expression of the cardiac SR $\mathrm{Ca}^{2+}$ ATPase protein, SERCA2a, is not affected by GDX $[69,75,96]$. Thus, there is no evidence that a reduction in the expression of SERCA2a can account for the decrease in $\mathrm{SR} \mathrm{Ca}^{2+}$ content in GDX hearts.

Other investigators have examined the expression of the endogenous SERCA2a inhibitor, PLB, after chronic testosterone withdrawal (Table 5). There is good agreement that PLB protein expression is similar in shamoperated and GDX hearts $[69,75,76,96]$. However, the regulation of PLB by key signaling pathways is modified by GDX. It is well known that PLB is regulated by phosphorylation through both PKA and CaMKII pathways [106]. As shown in Table 5, there is strong evidence that phosphorylation of PLB at the CaMKII site $\left(\mathrm{Thr}^{17}\right)$ is reduced by GDX $[69,96]$. There is also evidence that PLB phosphorylation at the PKA site $\left(\mathrm{Ser}^{16}\right)$ is reduced by GDX [69], although this is not seen in all studies [96]. As phosphorylation of PLB at both the PKA and CaMKII sites increases the activity of SERCA2a [106], a reduction in phosphorylation at these sites would be expected to reduce SERCA2a activity. This agrees with reports that SERCA activity is reduced by GDX ([96] but c.f. [76]). This reduction in the rate of $\mathrm{SR} \mathrm{Ca}^{2+}$ may explain the slower $\mathrm{Ca}^{2+}$ transient decay $[76,99]$ and reduction in $\mathrm{SR} \mathrm{Ca}^{2+}$ content [76] characteristic of cardiomyocytes from GDX animals.

Although information is limited, there is evidence that the cAMP/PKA and CaMKII pathways are modulated by androgens. It is known that cAMP levels are higher in cardiomyocytes from young adult male mice when compared to females [102]. While this is due, at least in part, to increased expression of phosphodiesterase 4B in female cells [102], testosterone also may play a role. In support of this, testosterone has been shown to inhibit phosphodiesterase and increase cAMP levels in rat atria and ventricles [107]. Thus, cAMP would be expected to fall in animals subjected to chronic GDX. Testosteroneassociated changes in the CaMKII pathway also are likely to occur in the setting of GDX, as CaMKII is activated by intracellular $\mathrm{Ca}^{2+}$, which is reduced by GDX (Table 4). Additional studies that explore the impact of androgens on pathways involved in post-translational modifications of $\mathrm{SR} \mathrm{Ca}^{2+}$ release mechanisms in the heart would be of interest.

\section{Acute effects of testosterone on cardiac $\mathrm{Ca}^{2+}$-handling mechanisms}

Although most studies have explored the effects of chronic testosterone exposure and/or deprivation on the heart, others have examined acute (nongenomic) effects of testosterone in cardiac muscle and isolated cardiomyocytes. It is well established that physiological testosterone levels fluctuate between 10 and $35 \mathrm{nM}$ in adult men [108], and similar levels are seen in male rodents [109]. However, as outlined below, experimental studies of acute testosterone application have typically used supra-physiological concentrations to assess actions on cardiac $\mathrm{Ca}^{2+}$-handling mechanisms.

There is evidence that testosterone can acutely affect the cardiac AP, at least when higher concentrations of androgens are used. Acute application of testosterone has no effect on RMP but prolongs APD in guinea pig papillary muscle preparations when high concentrations are used (e.g., 1,000 $\mu \mathrm{M})$ [110]. On the other hand, acute application of lower concentrations of testosterone (e.g., $100 \mathrm{nM}$ ) actually shortens APD in guinea pig ventricular myocytes [111]. Furthermore, lower concentrations of testosterone also can acutely affect ionic currents in isolated cardiomyocytes. For example, Michels et al. [93] reported that $10 \mu \mathrm{M}$ testosterone reduces peak T-type $\mathrm{Ca}^{2+}$ current in neonatal rat cardiomyocytes. Furthermore, even lower concentrations of testosterone (100 $\mathrm{nM}$ ) inhibit peak $\mathrm{I}_{\mathrm{Ca}-\mathrm{L}}$ in ventricular myocytes isolated from neonatal rats [92] and adult guinea pigs [111]. Superfusion of isolated rabbit ventricular myocytes with 3 to $10 \mathrm{nM}$ concentrations of the potent androgen DHT increases the magnitude of $I_{K 1}$ [112] and application of $100 \mathrm{nM}$ testosterone enhances $\mathrm{I}_{\mathrm{Ks}}$ in guinea pig ventricular myocytes [111]. These studies demonstrate that testosterone and its analogs can acutely modify the cardiac AP and underlying ionic currents, although whether these effects are relevant in vivo is unclear because most studies used supra-physiological concentrations of drug.

Others have examined effects of acute testosterone application on cardiomyocyte $\mathrm{Ca}^{2+}$ handling directly. One group has shown that acute application of testosterone $(100 \mathrm{nM})$ elicits voltage-dependent oscillations in intracellular $\mathrm{Ca}^{2+}$, along with $\mathrm{IP}_{3}$-receptor-mediated $\mathrm{Ca}^{2+}$ release from SR stores in neonatal rat ventricular myocytes [53]. By contrast, another study demonstrated that acute application of $1 \mu \mathrm{M}$ testosterone had no effect on either the amplitudes or time courses of contractions in ventricular myocytes isolated from adult female rats [113]. This latter study also showed that $1 \mu \mathrm{M}$ testosterone did not affect the amplitude or time course of the $\mathrm{Ca}^{2+}$ transient [113]. Whether differences between neonatal and adult ventricular myocytes account for these differing results is not yet clear. Importantly, the Beesley et al. [113] study showed that even high concentrations of testosterone have no acute effects on $\mathrm{Ca}^{2+}$ homeostasis or contractions in cells from females. As most studies of the effects of testosterone on the heart have used cells from males, it is possible that there are male-female differences in responses to testosterone, and additional studies to address this issue are needed. These acute effects of androgens on the heart are seen only at high concentrations of steroid, so the physiological relevance 
of these findings is uncertain. Additional studies that explore the impact of more physiological concentrations on cardiac $\mathrm{Ca}^{2+}$-handling mechanisms are warranted.

\section{Conclusions}

The evidence reviewed here suggests that chronic testosterone withdrawal influences cardiac $\mathrm{Ca}^{2+}$-handling mechanisms in ventricular myocytes, as illustrated in Figure 2. APD is prolonged in the absence of testosterone, an effect mediated by a decrease in magnitude of the repolarizing $\mathrm{K}^{+}$current, $\mathrm{I}_{\mathrm{Kur}}$ at least in rodent models. This reduction in $\mathrm{I}_{\mathrm{Kur}}$ is secondary to a decrease in the expression of $\mathrm{Kv1.5} . \mathrm{Ca}^{2+}$ transients also are smaller and slower in ventricular myocytes from GDX animals when compared to sham-operated controls, especially when cells are paced at physiological rates. The decrease in $\mathrm{SR} \mathrm{Ca}^{2+}$ release arises as a consequence of changes in several components of the excitationcontraction coupling pathway. First, GDX reduces the density of L-type $\mathrm{Ca}^{2+}$ channels, so $\mathrm{Ca}^{2+}$ influx is reduced and there is less $\mathrm{Ca}^{2+}$ available to trigger SR $\mathrm{Ca}^{2+}$ release. Second, the amount of $\mathrm{SR} \mathrm{Ca}^{2+}$ available for release is reduced by GDX, and the magnitude of $\mathrm{Ca}^{2+}$ sparks may decline. The decay of the $\mathrm{Ca}^{2+}$ transient is slowed as a consequence of a decrease in the rate of SR $\mathrm{Ca}^{2+}$ uptake along with prolongation of the APD. The decline in $\mathrm{SR} \mathrm{Ca}^{2+}$ uptake arises through a reduction in phosphorylation of PLB by CaMKII and possibly also by PKA. Contractions are attenuated in GDX myocytes due to a decrease in the magnitude of the $\mathrm{Ca}^{2+}$ transient along with a reduction in the maximal myofilament responsiveness to $\mathrm{Ca}^{2+}$. Relaxation is slowed due to slower $\mathrm{Ca}^{2+}$ transient decay along with a shift from the fast $\alpha$ $\mathrm{MHC}$ isoform to the slower $\beta$-MHC isoform. These

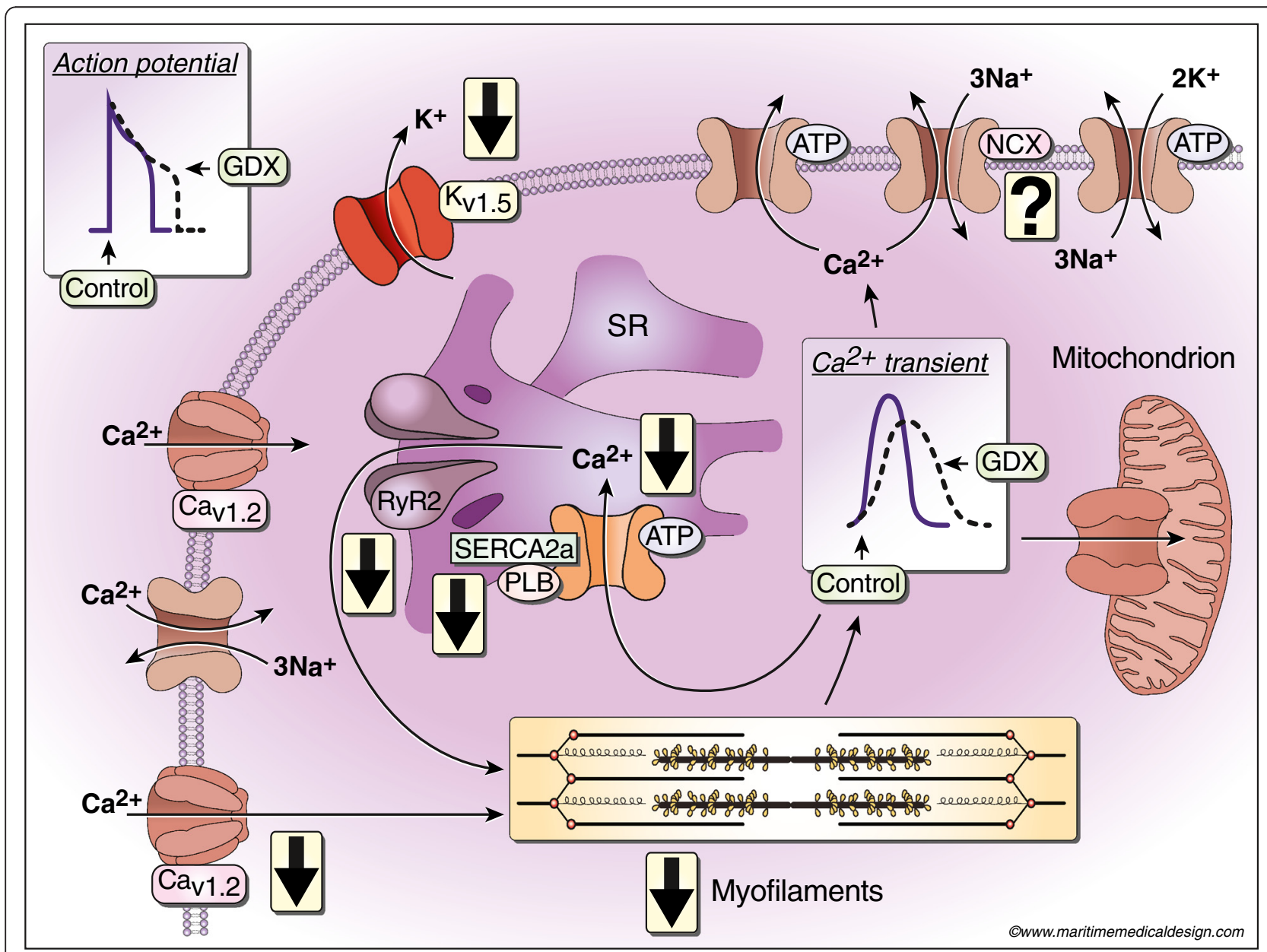

Figure 2 Impact of GDX on intracellular $\mathrm{Ca}^{2+}$-handling mechanisms in ventricular myocytes isolated from rodent hearts. APD is prolonged by $\mathrm{GDX}$, due to a decrease in repolarizing $\mathrm{K}^{+}$currents $\left(\mathrm{I}_{\mathrm{Kur}}\right)$ and a reduction in the expression of $\mathrm{Kv} 1.5$. Reduced $\mathrm{Ca}^{2+}$ influx along with smaller $\mathrm{Ca}^{2+}$ sparks attenuates SR $\mathrm{Ca}^{2+}$ release. $\mathrm{Ca}^{2+}$ transient decay is slowed by longer APs and slower SR $\mathrm{Ca}^{2+}$ uptake mediated by a decrease in phosphorylation of PLB by CaMKII (and possibly PKA). Peak contractions are attenuated through smaller peak $\mathrm{Ca}^{2+}$ transients and a decrease in maximal myofilament responsiveness to $\mathrm{Ca}^{2+}$. Contractions are slowed because SR $\mathrm{Ca}^{2+}$ uptake is reduced and the slower $\beta-\mathrm{MHC}$ isoform predominates. Whether NCX activity or expression is affected by GDX is not yet clear. 
findings demonstrate that GDX influences critical mechanisms involved in $\mathrm{Ca}^{2+}$ homeostasis and suggest that testosterone modulates myocardial function, at least in part, by effects on individual ventricular myocytes in rodent models. Additional experiments that explore the impact of testosterone on these mechanisms in cardiomyocytes from larger mammals including humans are needed and the key signaling pathways involved should be identified.

The idea that testosterone regulates the cardiac action potential and $\mathrm{Ca}^{2+}$ homeostasis at the level of the individual heart cell has a number of important clinical implications. For example, men have faster rates of repolarization than women [114], and castrated men have prolonged repolarization while the reverse is seen in women with abnormally high levels of testosterone [115]. This is consistent with evidence that GDX increases APD in individual myocytes in animal models. This may be clinically important as prolongation of the AP can increase the probability of early after depolarizations, which can trigger arrhythmias such as torsades des pointes [116,117]. Furthermore, it is well known that levels of testosterone decline with age, at the same time as the incidence of cardiovascular disease rises. Modifications in myocardial $\mathrm{Ca}^{2+}$ handling and contraction linked to falling testosterone levels in older adults are likely to interact with diseases in the aging heart. For example, the observation that contractions and $\mathrm{Ca}^{2+}$ transients decline in low-testosterone states may promote heart failure with reduced ejection fraction [118]. Intracellular $\mathrm{Ca}^{2+}$ dysregulation also is implicated in the pathogenesis of diseases such as myocardial ischemia and arrhythmias [119], where a decrease in testosterone may influence disease expression. Improved understanding of the cellular mechanisms involved in the effects of testosterone on the heart may reveal mechanisms involved in the increase in susceptibility to cardiovascular diseases in aging and may ultimately help identify new targets for intervention in the treatment of these diseases in both men and women.

\footnotetext{
Abbreviations

AP: Action potential; $\mathrm{APD}_{50}$ : AP duration at 50\% repolarization; CaMKII: $\mathrm{Ca}^{2+}$ calmodulin-dependent kinase II; CYP: Cytochrome P450; DHP: 1,4-dihydropyridine; DHEA: Dehydroepiandrosterone; DHT: Dihydrotestosterone; GDX: Gonadectomy; GnRH: Gonadotropin-releasing hormone; HSD3B: 3 $\beta$-hydroxysteroid dehydrogenase; HSD17B3: 17 $\beta$-hydroxysteroid dehydrogenase 3 ; I I 1 Inward rectifier $\mathrm{K}^{+}$current; LVDP: Left ventricular developed pressure; LVEDP: Left ventricular end-diastolic pressure; $\mathrm{I}_{\mathrm{Ca}-\mathrm{L}}$ : L-type $\mathrm{Ca}^{2+}$ current; LH: Luteinizing hormone; MHC: Myosin heavy chain; PLB: Phospholamban; PKA: Protein kinase $A ;+d P / d T$ : Rate of left ventricular pressure rise; $-d P / d T$ : Rate of left ventricular pressure decay; RMP: Resting membrane potential; RyR: Ryanodine receptor; SERCA: Sarco/endoplasmic reticulum Ca ${ }^{2+}$-ATPase; SR: Sarcoplasmic reticulum; $I_{\text {Ks: }}$ Slow delayed rectifier $\mathrm{K}^{+}$current; $\mathrm{NCX}: \mathrm{Na}^{+} / \mathrm{Ca}^{2+}$ exchanger; Iss: Steady state

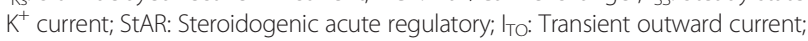
I Kur: Ultra-rapid delayed rectifier $\mathrm{K}^{+}$current.
}

\section{Competing interests}

The authors declare that they have no competing interests.

\section{Authors' contributions}

$\mathrm{SH}$ and OA developed the overall concept for this review, and both were involved in drafting the manuscript and revising it critically. Both authors have read and approved the final manuscript.

\section{Acknowledgements}

The authors express their appreciation to Peter Nicholl for technical assistance and artwork, as well as to Monique Guilderson of Maritime Medical Design for designing Figure 2. This study was supported by a grant from the Canadian Institutes for Health Research (MOP 97973).

Received: 28 January 2015 Accepted: 27 March 2015

Published online: 29 April 2015

\section{References}

1. Roger VL, Go AS, Lloyd-Jones DM, Benjamin EJ, Berry JD, Borden WB, et al. American Heart Association Statistics Committee and Stroke Statistics Subcommittee. Heart disease and stroke statistics-2012 update: a report from the American Heart Association. Circulation. 2012;125:e2-220.

2. Go AS, Mozaffarian D, Roger VL, Benjamin EJ, Berry JD, Borden WB, et al. American Heart Association Statistics Committee and Stroke Statistics Subcommittee. Heart disease and stroke statistics-2013 update: a report from the American Heart Association. Circulation. 2013;127:e6-245.

3. Vitale C, Mendelsohn ME, Rosano GM. Gender differences in the cardiovascular effect of sex hormones. Nat Rev Cardiol. 2009;6:532-42.

4. Oskui PM, French WJ, Herring MJ, Mayeda GS, Burstein S, Kloner RA. Testosterone and the cardiovascular system: a comprehensive review of the clinical literature. J Am Heart Assoc. 2013;2:e000272.

5. Araujo AB, O'Donnell AB, Brambilla DJ, Simpson WB, Longcope C, Matsumoto AM, et al. Prevalence and incidence of androgen deficiency in middle-aged and older men: estimates from the Massachusetts Male Aging Study. J Clin Endocrinol Metab. 2004;89:5920-6.

6. Pluchino N, Carmignani A, Cubeddu A, Santoro A, Cela V, Errasti T. Androgen therapy in women: for whom and when. Arch Gynecol Obstet. 2013;288:731-7.

7. Tsujimura A. The relationship between testosterone deficiency and men's health. World J Mens Health. 2013;31:126-35.

8. Edelman S, Butler J, Hershatter BW, Khan MK. The effects of androgen deprivation therapy on cardiac function and heart failure: implications for management of prostate cancer. Clin Genitourin Cancer. 2014;12(6):399-407.

9. Mirdamadi A, Garakyaraghi M, Pourmoghaddas A, Bahmani A, Mahmoudi H, Gharipour M. Beneficial effects of testosterone therapy on functional capacity, cardiovascular parameters, and quality of life in patients with congestive heart failure. Biomed Res Int. 2014;2014:392432.

10. Marsh JD, Lehmann MH, Ritchie RH, Gwathmey JK, Green GE, Schiebinger RJ. Androgen receptors mediate hypertrophy in cardiac myocytes. Circulation. 1998:98:256-61.

11. Lizotte E, Grandy SA, Tremblay A, Allen BG, Fiset C. Expression, distribution and regulation of sex steroid hormone receptors in mouse heart. Cell Physiol Biochem. 2009;23:75-86.

12. Bers DM. Cardiac sarcoplasmic reticulum calcium leak: basis and roles in cardiac dysfunction. Annu Rev Physiol. 2014;76:107-27.

13. Canty Jr JM, Suzuki G. Myocardial perfusion and contraction in acute ischemia and chronic ischemic heart disease. J Mol Cell Cardiol. 2012;52:822-31.

14. Blouin K, Richard C, Brochu G, Hould FS, Lebel S, Marceau S, et al. Androgen inactivation and steroid-converting enzyme expression in abdominal adipose tissue in men. J Endocrinol. 2006;191:637-49.

15. Miller WL, Auchus RJ. The molecular biology, biochemistry, and physiology of human steroidogenesis and its disorders. Endocr Rev. 2011;32:81-151.

16. O'Donnell L, Robertson KM, Jones ME, Simpson ER. Estrogen and spermatogenesis. Endocr Rev. 2001;22:289-318.

17. Bay K, Main KM, Toppari J, Skakkebæk NE. Testicular descent: INSL3, testosterone, genes and the intrauterine milieu. Nat Rev Urol. 2011;8:187-96.

18. Krause W. Androgens in the demography of male life course-a review. Soc Biol. 2006;53:4-12

19. Feldman HA, Longcope C, Derby CA, Johannes CB, Araujo AB, Coviello AD, et al. Age trends in the level of serum testosterone and other hormones in 
middle-aged men: longitudinal results from the Massachusetts male aging study. J Clin Endocrinol Metab. 2002;87:589-98.

20. O'Reilly MW, House PJ, Tomlinson JW. Understanding androgen action in adipose tissue. J Steroid Biochem Mol Biol. 2014;143:277-84

21. Zouboulis CC, Chen WC, Thornton MJ, Qin K, Rosenfield R. Sexual hormones in human skin. Horm Metab Res. 2007;39:85-95.

22. Braunstein GD, Reitz RE, Buch A, Schnell D, Caulfield MP. Testosterone reference ranges in normally cycling healthy premenopausal women. J Sex Med. 2011:8:2924-34.

23. Davison SL, Davis SR. Androgens in women. J Steroid Biochem Mol Biol. 2003;85:363-6.

24. Machida T, Yonezawa Y, Noumura T. Age-associated changes in plasma testosterone levels in male mice and their relation to social dominance or subordinance. Horm Behav. 1981;15:238-45.

25. Fujita S, Chiba M, Ohta M, Kitani K, Suzuki T. Alteration of plasma sex hormone levels associated with old age and its effect on hepatic drug metabolism in rats. J Pharmacol Exp Ther. 1990;253:369-74.

26. Borst SE, Mulligan T. Testosterone replacement therapy for older men. Clin Interv Aging. 2007;2:561-6.

27. Herbison AE, Porteous R, Pape JR, Mora JM, Hurst PR. Gonadotropin-releasing hormone neuron requirements for puberty, ovulation, and fertility. Endocrinology. 2008;149:597-604.

28. Levine JE. New concepts of the neuroendocrine regulation of gonadotropin surges in rats. Biol Reprod. 1997;56:293-302.

29. Chen H, Midzak A, Luo L, Zirkin BR. Aging and the decline of androgen production. In: Payne AH, Hardy MP, editors. The Leydig cell in health and disease. Totowa, New Jersey: Humana Press; 2007. p. 117-31.

30. Miller WL. Steroid hormone synthesis in mitochondria. Mol Cell Endocrinol. 2013:379:62-73.

31. Ye L, Su ZJ, Ge RS. Inhibitors of testosterone biosynthetic and metabolic activation enzymes. Molecules. 2011;16:9983-10001.

32. Hanukoglu I. Steroidogenic enzymes: structure, function, and role in regulation of steroid hormone biosynthesis. J Steroid Biochem Mol Biol. 1992;43:779-804

33. Stocco C. Tissue physiology and pathology of aromatase. Steroids. 2012;77:27-35

34. Bell JR, Mellor KM, Wollermann AC, Delbridge LM. Aromatase deficiency confers paradoxical postischemic cardioprotection. Endocrinology. 2011;152:4937-47.

35. Cohen PG. Obesity in men: the hypogonadal-estrogen receptor relationship and its effect on glucose homeostasis. Med Hypotheses. 2008;70:358-60.

36. Cheatham SA, Hosey RG, Johnson DL. Performance-enhancing drugs and today's athlete: a growing concern. Orthopedics. 2008:31:10

37. Hoffman JR, Ratamess NA. Medical issues associated with anabolic steroid use: are they exaggerated? J Sports Sci Med. 2006;5:182-93.

38. Brouillette J, Trépanier-Boulay V, Fiset C. Effect of androgen deficiency on mouse ventricular repolarization. J Physiol. 2003;546:403-13.

39. Brouillette J, Rivard K, Lizotte E, Fiset C. Sex and strain differences in adult mouse cardiac repolarization: importance of androgens. Cardiovasc Res. 2005;65:148-57.

40. Pham TV, Robinson RB, Danilo Jr P, Rosen MR. Effects of gonadal steroids on gender-related differences in transmural dispersion of L-type calcium current. Cardiovasc Res. 2002:53:752-62.

41. Midzak AS, Chen H, Papadopoulos V, Zirkin BR. Leydig cell aging and the mechanisms of reduced testosterone synthesis. Mol Cell Endocrinol. 2009;299:23-31.

42. Zirkin BR, Tenover JL. Aging and declining testosterone: past, present, and hopes for the future. J Androl. 2012;33:1111-8.

43. Matsumoto T, Sakari M, Okada M, Yokoyama A, Takahashi S, Kouzmenko A, et al. The androgen receptor in health and disease. Annu Rev Physiol. 2013;75:201-24.

44. Ahtiainen JP, Hulmi JJ, Kraemer WJ, Lehti M, Nyman K, Selänne H, et al. Heavy resistance exercise training and skeletal muscle androgen receptor expression in younger and older men. Steroids. 2011;76:183-92.

45. Dart DA, Waxman J, Aboagye EO, Bevan CL. Visualising androgen receptor activity in male and female mice. PLoS One. 2013;8:e71694

46. McGill Jr HC, Anselmo VC, Buchanan JM, Sheridan PJ. The heart is a target organ for androgen. Science. 1980;207:775-7.

47. Lin AL, McGill Jr HC, Shain SA. Hormone receptors of the baboon cardiovascular system. Biochemical characterization of myocardial cytoplasmic androgen receptors. Circ Res. 1981;49:1010-6.
48. Jiang M, Ma Y, Chen C, Fu X, Yang S, Li X, et al. Androgen-responsive gene database: integrated knowledge on androgen-responsive genes. Mol Endocrinol. 2009;23:1927-33.

49. Jin HJ, Kim J, Yu J. Androgen receptor genomic regulation. Transl Androl Urol. 2013;2:157-77.

50. Walker WH. Testosterone signaling and the regulation of spermatogenesis. Spermatogenesis. 2011;1:116-20.

51. Perusquía M, Stallone JN. Do androgens play a beneficial role in the regulation of vascular tone? Nongenomic vascular effects of testosterone metabolites. Am J Physiol Heart Circ Physiol. 2010;298:H1301-7.

52. Vicencio JM, Estrada M, Galvis D, Bravo R, Contreras AE, Rotter D, et al. Anabolic androgenic steroids and intracellular calcium signaling: a mini review on mechanisms and physiological implications. Mini Rev Med Chem. 2011;11:390-8.

53. Vicencio JM, Ibarra C, Estrada M, Chiong M, Soto D, Parra V, et al. Testosterone induces an intracellular calcium increase by a nongenomic mechanism in cultured rat cardiac myocytes. Endocrinology. 2006;147:1386-95.

54. Buonanno C, Arbustini E, Rossi L, Dander B, Vassanelli C, Paris B, et al. Left ventricular function in men and women. Another difference between sexes. Eur Heart J. 1982;3:525-8.

55. Hanley PC, Zinsmeister AR, Clements IP, Bove AA, Brown ML, Gibbons RJ. Gender-related differences in cardiac response to supine exercise assessed by radionuclide angiography. J Am Coll Cardiol. 1989;13:624-9.

56. Merz CN, Moriel M, Rozanski A, Klein J, Berman DS. Gender-related differences in exercise ventricular function among healthy subjects and patients. Am Heart J. 1996;131:704-9.

57. Parks RJ, Howlett SE. Sex differences in mechanisms of cardiac excitation-contraction coupling. Pflugers Arch. 2013;465:747-63.

58. Woerdeman J, de Ronde W. Therapeutic effects of anabolic androgenic steroids on chronic diseases associated with muscle wasting. Expert Opin Investig Drugs. 2011;20:87-97.

59. Kanayama G, Hudson J, Pope Jr HG. Illicit anabolic-androgenic steroid use. Horm Behav. 2010;58:111-21.

60. Angell PJ, Chester N, Green DJ, Shah R, Somauroo J, Whyte G, et al. Anabolic steroid use and longitudinal, radial, and circumferential cardiac motion. Med Sci Sports Exerc. 2012;44:583-90.

61. Nottin S, Nguyen LD, Terbah M, Obert P. Cardiovascular effects of androgenic anabolic steroids in male bodybuilders determined by tissue Doppler imaging. Am J Cardiol. 2006;97:912-5.

62. De Piccoli B, Giada F, Benettin A, Sartori F, Piccolo E. Anabolic steroid use in body builders: an echocardiographic study of left ventricle morphology and function. Int J Sports Med. 1991;12:408-12.

63. Urhausen A, Hölpes R, Kindermann W. One- and two-dimensional echocardiography in bodybuilders using anabolic steroids. Eur J Appl Physiol Occup Physiol. 1989;58:633-40.

64. Hajimoradi B, Kazerani H. Echocardiographic findings in power athletes abusing anabolic androgenic steroids. Asian I Sports Med. 2013;4:10-4.

65. Thompson PD, Sadaniantz A, Cullinane EM, Bodziony KS, Catlin DH, Torek-Both $\mathrm{G}$, et al. Left ventricular function is not impaired in weight-lifters who use anabolic steroids. J Am Coll Cardiol. 1992;19:278-82.

66. Palatini P, Giada F, Garavelli G, Sinisi F, Mario L, Michieletto M, et al. Cardiovascular effects of anabolic steroids in weight-trained subjects. J Clin Pharmacol. 1996;36:1132-40.

67. Salke RC, Rowland TW, Burke EJ. Left ventricular size and function in body builders using anabolic steroids. Med Sci Sports Exerc. 1985;17:701-4.

68. Angell PJ, Ismail TF, Jabbour A, Smith G, Dahl A, Wage R, et al. Ventricular structure, function, and focal fibrosis in anabolic steroid users: a CMR study Eur J Appl Physiol. 2014;114:921-8.

69. Sebag IA, Gillis MA, Calderone A, Kasneci A, Meilleur M, Haddad R, et al. Sex hormone control of left ventricular structure/function: mechanistic insights using echocardiography, expression, and DNA methylation analyses in adult mice. Am J Physiol Heart Circ Physiol. 2011;301:H1706-15.

70. LeGros T, McConnell D, Murry T, Edavettal M, Racey-Burns LA, Shepherd RE, et al. The effects of 17 alpha-methyltestosterone on myocardial function in vitro. Med Sci Sports Exerc. 2000;32:897-903.

71. Rocha FL, Carmo EC, Roque FR, Hashimoto NY, Rossoni LV, Frimm C, et al. Anabolic steroids induce cardiac renin-angiotensin system and impair the beneficial effects of aerobic training in rats. Am J Physiol Heart Circ Physiol. 2007;293:H3575-83.

72. Bocalini DS, Beutel A, Bergamaschi CT, Tucci PJ, Campos RR. Treadmill exercise training prevents myocardial mechanical dysfunction induced by androgenic-anabolic steroid treatment in rats. PLoS One. 2014;9:e87106. 
73. Liang MT, Paulson DJ, Kopp SJ, Glonek T, Meneses P, Gierke LW, et al. Effects of anabolic steroids and endurance exercise on cardiac performance. Int J Sports Med. 1993;14:324-9.

74. Eleawa SM, Sakr HF, Hussein AM, Assiri AS, Bayoumy NM, Alkhateeb M. Effect of testosterone replacement therapy on cardiac performance and oxidative stress in orchidectomized rats. Acta Physiol (Oxf). 2013;209:136-47.

75. Callies F, Strömer $H$, Schwinger RH, Bölck B, Hu K, Frantz $\mathrm{S}$, et al. Administration of testosterone is associated with a reduced susceptibility to myocardial ischemia. Endocrinology. 2003;144:4478-83.

76. Tsang S, Wong SS, Wu S, Kravtsov GM, Wong TM. Testosterone-augmented contractile responses to alpha1- and beta1-adrenoceptor stimulation are associated with increased activities of RyR, SERCA, and NCX in the heart. Am J Physiol Cell Physiol. 2009;296:C766-82.

77. Schaible TF, Malhotra A, Ciambrone G, Scheuer J. The effects of gonadectomy on left ventricular function and cardiac contractile proteins in male and female rats. Circ Res. 1984;54:38-49.

78. Scheuer J, Malhotra A, Schaible TF, Capasso J. Effects of gonadectomy and hormonal replacement on rat hearts. Circ Res. 1987;61:12-9.

79. Bell JR, Bernasochi GB, Varma U, Boon WC, Ellem SJ, Risbridger GP, et al. Aromatase transgenic upregulation modulates basal cardiac performance and the response to ischemic stress in male mice. Am J Physiol Heart Circ Physiol. 2014;306:H1265-74.

80. Greenstein JL, Winslow RL. Integrative systems models of cardiac excitation-contraction coupling. Circ Res. 2011;108:70-84.

81. Bers DM. Calcium cycling and signaling in cardiac myocytes. Annu Rev Physiol. 2008;70:23-49.

82. Cheng H, Lederer WJ. Calcium sparks. Physiol Rev. 2008;88:1491-545.

83. Ottolia M, Torres N, Bridge JH, Philipson KD, Goldhaber JI. Na/Ca exchange and contraction of the heart. J Mol Cell Cardiol. 2013;61:28-33.

84. D'Antona G, Gualea MR, Ceriani T. Effects of gonadectomy, testosterone replacement and supplementation on cardiac action potentials in the rat. Basic Appl Myol. 2001;11:23-9.

85. MacDonald JK, Pyle WG, Reitz CJ, Howlett SE. Cardiac contraction, calcium transients, and myofilament calcium sensitivity fluctuate with the estrous cycle in young adult female mice. Am J Physiol Heart Circ Physiol. 2014;306:H938-53

86. Saito T, Ciobotaru A, Bopassa JC, Toro L, Stefani E, Eghbali M. Estrogen contributes to gender differences in mouse ventricular repolarization. Circ Res. 2009;105:343-52.

87. James AF, Arberry LA, Hancox JC. Gender-related differences in ventricular myocyte repolarization in the guinea pig. Basic Res Cardiol. 2004;99:183-92.

88. Nerbonne JM, Kass RS. Molecular physiology of cardiac repolarization. Physiol Rev. 2005;85:1205-53.

89. Zhu Y, Ai X, Oster RA, Bers DM, Pogwizd SM. Sex differences in repolarization and slow delayed rectifier potassium current and their regulation by sympathetic stimulation in rabbits. Pflugers Arch. 2013;465:805-18.

90. Golden KL, Marsh JD, Jiang Y. Castration reduces mRNA levels for calcium regulatory proteins in rat heart. Endocrine. 2002;19:339-44.

91. Golden KL, Marsh JD, Jiang Y, Brown T, Moulden J. Gonadectomy of adult male rats reduces contractility of isolated cardiac myocytes. Am J Physiol Endocrinol Metab. 2003;285:E449-53.

92. Er F, Michels G, Brandt MC, Khan I, Haase H, Eicks M, et al. Impact of testosterone on cardiac L-type calcium channels and $\mathrm{Ca}^{2+}$ sparks: acute actions antagonize chronic effects. Cell Calcium. 2007:41:467-77.

93. Michels G, Er F, Eicks M, Herzig S, Hoppe UC. Long-term and immediate effect of testosterone on single T-type calcium channel in neonatal rat cardiomyocytes. Endocrinology. 2006;147:5160-9.

94. Er F, Gassanov N, Brandt MC, Madershahian N, Hoppe UC. Impact of dihydrotestosterone on L-type calcium channels in human ventricular cardiomyocytes. Endocr Res. 2009;34:59-67.

95. Fink M, Noble D. Pharmacodynamic effects in the cardiovascular system: the modeller's view. Basic Clin Pharmacol Toxicol. 2010;106:243-9.

96. Witayavanitkul N, Woranush W, Bupha-Intr T, Wattanapermpool J. Testosterone regulates cardiac contractile activation by modulating SERCA but not NCX activity. Am J Physiol Heart Circ Physiol. 2013;304:H465-72.

97. Golden KL, Marsh JD, Jiang Y, Moulden J. Acute actions of testosterone on contractile function of isolated rat ventricular myocytes. Eur J Endocrinol. 2005;152:479-83.

98. Bell JR, Bernasochi GB, Wollermann AC, Raaijmakers AJ, Boon WC, Simpson $E R$, et al. Myocardial and cardiomyocyte stress resilience is enhanced in aromatase-deficient female mouse hearts through CaMKIII activation. Endocrinology. 2015;en20141700. [Epub ahead of print]

99. Curl CL, Delbridge LM, Canny BJ, Wendt IR. Testosterone modulates cardiomyocyte $\mathrm{Ca}^{2+}$ handling and contractile function. Physiol Res. 2009;58(2):293-7.

100. Golden KL, Marsh JD, Jiang Y, Moulden J. Gonadectomy alters myosin heavy chain composition in isolated cardiac myocytes. Endocrine. 2004;24:137-40.

101. Louch WE, Hake J, Jølle GF, Mørk HK, Sjaastad I, Lines GT, et al. Control of $\mathrm{Ca}^{2+}$ release by action potential configuration in normal and failing murine cardiomyocytes. Biophys J. 2010;99:1377-86.

102. Parks RJ, Ray G, Bienvenu LA, Rose RA, Howlett SE. Sex differences in SR Ca ${ }^{2}$ + release in murine ventricular myocytes are regulated by the CAMP/PKA pathway. J Mol Cell Cardiol. 2014;75:162-73.

103. Farrell SR, Ross JL, Howlett SE. Sex differences in mechanisms of cardiac excitation-contraction coupling in rat ventricular myocytes. Am J Physiol Heart Circ Physiol. 2010;299:H36-45.

104. Parks RJ, Howlett SE. H-89 decreases the gain of excitation-contraction coupling and attenuates calcium sparks in the absence of beta-adrenergic stimulation. Eur J Pharmacol. 2012;691:163-72.

105. Guo T, Zhang T, Mestril R, Bers DM. Ca ${ }^{2+} /$ Calmodulin-dependent protein kinase II phosphorylation of ryanodine receptor does affect calcium sparks in mouse ventricular myocytes. Circ Res. 2006;99:398-406.

106. Maier LS. CaMKII overexpression in hypertrophy and heart failure: cellular consequences for excitation-contraction coupling. Braz J Med Biol Res. 2005;38:1293-302.

107. Bordallo J, Cantabrana B, Suárez L, Sánchez M. Testosterone inhibits CAMP-phosphodiesterases in heart extracts from rats and increases CAMP levels in isolated left atria. Pharmacology. 2011;87:155-60.

108. Czubryt MP, Espira L, Lamoureux L, Abrenica B. The role of sex in cardiac function and disease. Can J Physiol Pharmacol. 2006;84:93-109.

109. McNamara KM, Harwood DT, Simanainen U, Walters KA, Jimenez M, Handelsman DJ. Measurement of sex steroids in murine blood and reproductive tissues by liquid chromatography-tandem mass spectrometry. J Steroid Biochem Mol Biol. 2010;121:611-8.

110. Zhang Y, Hao YC, Song LL, Guo SM, Gu SZ, Lu SG. Effects of sex hormones on action potential and contraction of guinea pig papillary muscle. Zhongguo Yao Li Xue Bao. 1998;19:248-50.

111. Bai CX, Kurokawa J, Tamagawa M, Nakaya H, Furukawa T. Nontranscriptional regulation of cardiac repolarization currents by testosterone. Circulation. 2005;112(12):1701-10.

112. Carnes CA, Dech SJ. Effects of dihydrotestosterone on cardiac inward rectifier $\mathrm{K}^{+}$current. Int J Androl. 2002;25:210-4.

113. Beesley RD, Palmer BM, Casson PR, Toth MJ. Effects of testosterone on cardiomyocyte calcium homeostasis and contractile function in female rats. Exp Physiol. 2013;98:161-71.

114. Vicente J, Johannesen L, Galeotti L, Strauss DG. Mechanisms of sex and age differences in ventricular repolarization in humans. Am Heart J. 2014;168:749-56.

115. Bidoggia H, Maciel JP, Capalozza N, Mosca S, Blaksley EJ, Valverde E, et al. Sex differences on the electrocardiographic pattern of cardiac repolarization: possible role of testosterone. Am Heart J. 2000;140(4):678-83.

116. January CT, Riddle JM. Early afterdepolarizations: mechanism of induction and block. A role for L-type Ca2+ current. Circ Res. 1989;64:977-90.

117. Guo D, Zhao X, Wu Y, Liu T, Kowey PR, Yan GX. L-type calcium current reactivation contributes to arrhythmogenesis associated with action potential triangulation. J Cardiovasc Electrophysiol. 2007;18:196-203.

118. Dunlay SM, Roger VL. Gender differences in the pathophysiology, clinical presentation, and outcomes of ischemic heart failure. Curr Heart Fail Rep. 2012:9:267-76.

119. Doroudgar S, Glembotski CC. New concepts of endoplasmic reticulum function in the heart: programmed to conserve. J Mol Cell Cardiol. 2013;55:85-91. 